\title{
8 The economic consequences of globalisation in the United States
}

\author{
Peter A. Petri and Meenal Banga
}

\section{The globalisation debate}

In 1999, Merrill Lynch, a leading wealth manager in the US, took out full-page ads in major US newspapers to celebrate the era of globalisation: 'The World Is 10 Years Old. It was born when the Wall fell in 1989.' The ads argued that the 'spread of free markets and democracy around the world is permitting more people everywhere to turn their aspirations into achievements. And technology, properly harnessed and liberally distributed, has the power to erase not just geographical borders but also human ones.'

The current era of globalisation began in the 1970s, when the share of trade in world output was around 10\% (Figure 8.1). Globalisation accelerated in the 1980 s, when the share of world trade in output surpassed historical records, eventually climbing to about $25 \%$ by 2009 . Since then, the trade share of GDP has flattened. For reasons ranging from trade policy to technological changes and the maturation of international supply chains, trade intensity is not likely to rise as fast in the future as it did in recent decades.

The unprecedented rise in global interdependence has been very productive. World GDP growth, which hovered in the $2 \%$ per year range in the 1970 s and early 1980s, doubled to reach the $4 \%$ range before the global financial crisis. Growth spread to the world's largest countries and lifted more than a billion people out of extreme poverty. New global supply chains brought emerging, trade-oriented economies into the network of global expansion. However, the fragility of rapid, interdependent growth also became apparent. In 2008, Merrill Lynch succumbed to the global financial crisis. Meanwhile, criticism of the distributional effects of globalisation, particularly in advanced countries, intensified as Piketty (2015) and others brought inequality and wage stagnation to the forefront of public debate.

The chief concern in the US is that the economy is delivering a disproportionate share of gains to the wealthiest few. According to Census data, from 1970 to 2018 the median US household income rose from $\$ 50,545$ to $\$ 63,179$, or by $0.46 \%$ per year, while that of the top $5 \%$ of households rose from $\$ 192,603$ to $\$ 416,520$, or by $1.62 \%$ per year (Semega et al., 2019). In 1970, a highincome household earned 3.8 times as much as the median household, but this 


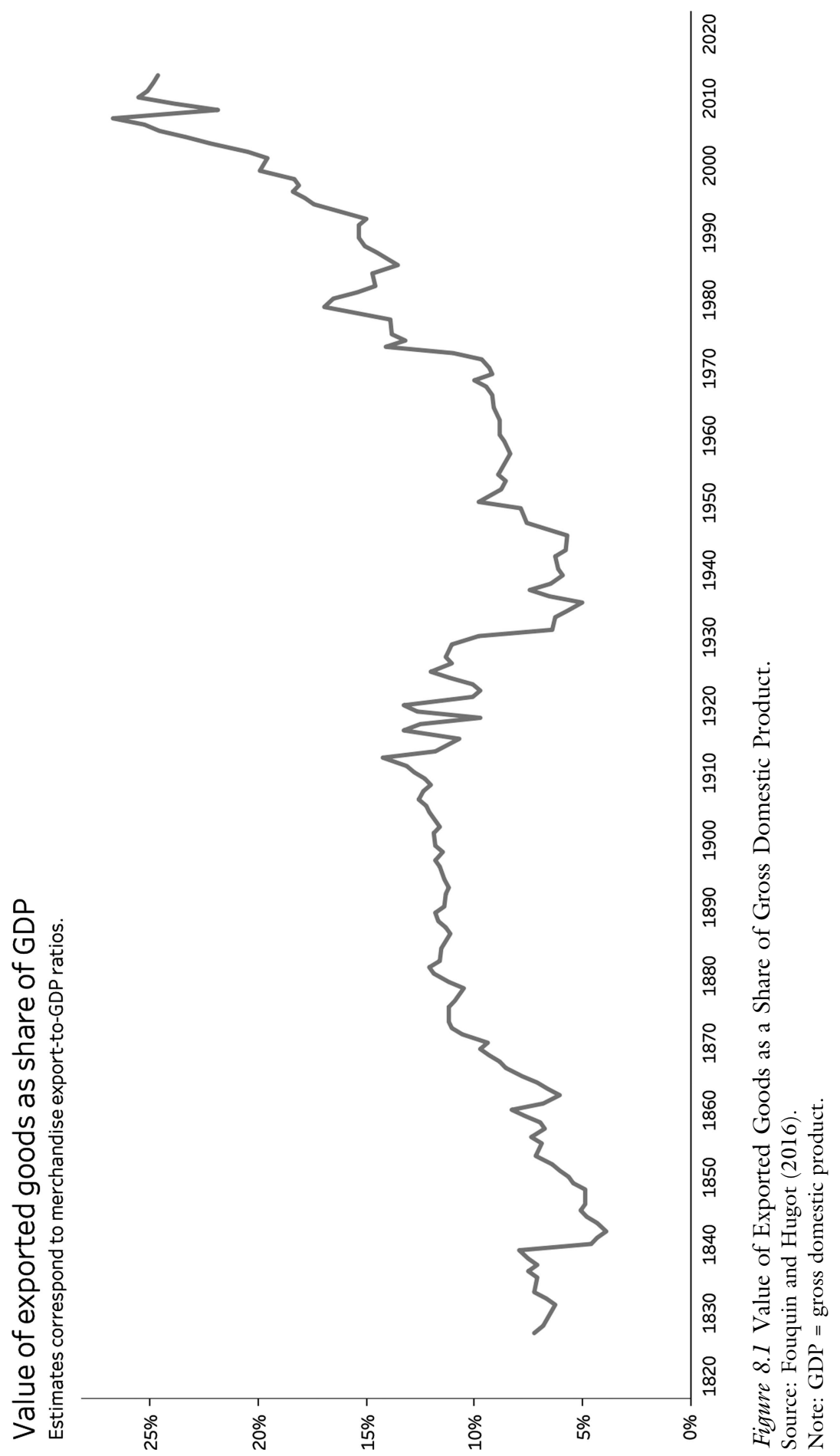




\section{Peter A. Petri and Meenal Banga}

ratio had grown to 6.6 by 2018 . Still more extreme contrasts emerged between richer and poorer households, and amongst subgroups by levels of education. In turn, inequality may have contributed to other trends such as withdrawal from the labour force, increased mortality and morbidity, and political polarisation. These trends are not direct results of globalisation, but they are often attributed to trade in popular discussions.

This paper attempts to dissect the consequences of globalisation. Rather than offering new research, it reviews the extensive literature on these issues, including about 20 studies with significant influence on the debate. These studies span three subfields: the overall gains from trade, adverse labour market trends and the causal effects of trade, and the results of changes in trade policy.

- Studies on the overall effects of globalisation suggest large gains. Although these results are important to our analysis, this review is relatively brief since the findings reflect familiar theoretical ground and its empirical results broadly agree on the magnitude of gains from trade.

- Studies of US labour market data reveal significant adverse trends, which include extreme cases of very harmful effects. Yet globalisation is only one of several factors that appear to be at work, including technological progress, demand shifts, and diverging, unrelated trends in economic activity across sectors and locations.

- Studies of specific policy changes have findings broadly consistent with those of the first two areas of research - that the overall effects of increased trade have been positive. However, these gains coincided with adverse labour market trends that were most likely attributable to other factors.

The adverse side effects of globalisation require policy attention, but the evidence suggests that erecting trade barriers is a poor response. For one thing, past trade changes have already resulted in adjustments that cannot be reversed without imposing further costs on workers and consumers. Better approaches will focus on making workers more productive through education and mobility, and distributing the gains from globalisation more equally through fiscal policies.

Section 2 of this paper examines the gains from globalisation. Section 3 addresses developments in labour markets. Section 4 surveys the ex-post effects of the North American Free Trade Agreement (NAFTA) and permanent normal trade relations (PNTR) with China. Section 5 concludes.

\section{The gains from globalisation}

The case for economic integration is well known, and recent empirical estimates suggest substantial benefits from global trade and deeper integration by groups of countries. Strong anecdotal evidence supports this positive view - in addition to relieving extreme poverty in developing countries, interdependence enables consumers to enjoy unprecedented variety, quality, and availability of goods and services everywhere. 
Federico and Tena-Junguito (2016) estimated that the increase in the share of world trade in GDP since the 1950s has added about 5 percentage points to world income (Figure 8.2). Given world GDP of $\$ 85$ trillion in 2018 , the incremental benefits from trade since the 1950s represent about $\$ 4.3$ trillion of world income. Globalisation has also stimulated flows of capital, technology, and talent, further raising incomes and improving well-being.

Additional studies suggest that the US has benefited from globalisation even more than the rest of the world. In a multi-study review, Bradford, Grieco, and Hufbauer (2005) concluded that advances in globalisation from 1947 to 2003 added $\$ 0.8$ trillion-\$1.5 trillion, or $11 \%-14 \%$, to the US GDP of \$11 trillion in 2003. Extrapolating these estimates to 2018 GDP suggests that changes in economic interdependence since 1947 added $\$ 2.2$ trillion-\$4.0 trillion to US GDP in 2018 , or $11 \%-19 \%$ of 2018 GDP of $\$ 20.5$ trillion. $^{1}$

Moreover, these benefits do not seem to have been exhausted. Bradford, Grieco, and Hufbauer (2005) surveyed estimates which suggest that further liberalisation of policy barriers could almost double these benefits. Despite controversies over the distribution of benefits from trade, the overall gains from globalisation for the US are so ubiquitous and widely accepted amongst economists that few have focused on refining or updating their magnitudes since Bradford's study. This contrasts with a much more active and voluminous body of research on how economic openness affects growth in developing economies.

Nevertheless, important related findings by Bernard et al. (2003) highlighted the determinants of productivity at the firm level. They found that exporting firms are much more productive than domestically focused firms, which in turn are more productive than firms vulnerable to import competition. Based on these results and the Eaton-Kortum trade model, they then simulated shifts from current levels of US openness to autarky. They found that these shifts would lead to productivity losses, accounting for $9 \%$ of the output of an average US producer. This estimate is within the range, in percentage terms, of those referenced above by Federico and Tena-Junguito (2016) and Bradford, Grieco, and Hufbauer (2005), although the three studies rely on very different methodologies.

Unlike many smaller economies, the US is less dependent on globalisation for finding new technologies and competitive challenges, or for accessing large markets and varieties of inputs. However, the US does benefit from globalisation through a different, important channel. Global supply chains enable US producers to concentrate on their most productive tasks while shifting less efficient tasks elsewhere. An early study of US offshoring found that outsourcing service tasks had significantly positive effects on the productivity of US firms, although offshoring of material inputs less so (Amiti and Wei, 2009). With recent data and a broader definition of supply chains, Constantinescu, Mattoo, and Ruta (2019) showed that embedding foreign value added in production generally increases productivity across US sectors, especially in industries producing exports. Results from Formai and Vergara Caffarelli (2016) confirm these findings, demonstrating that the results appear mainly in 'fragmentable' sectors, i.e. industries where supply chains are easily divided into tasks. 


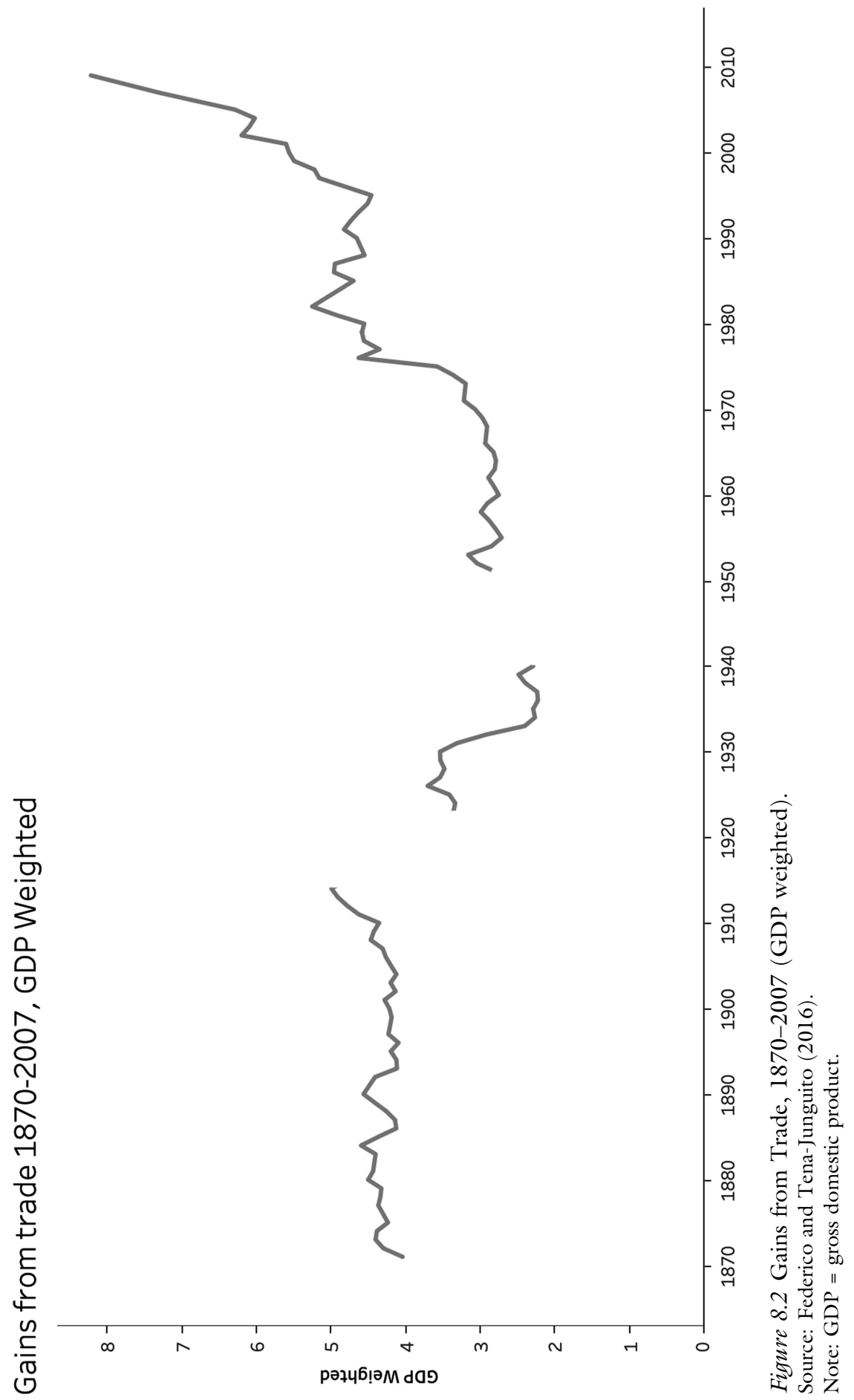


Finally, globalisation has enormously benefited US innovation - a rapidly expanding sector of the US economy. These gains appear through channels ranging from the inflow of ideas and money to attracting talent. Global markets also increase returns on ideas, which are non-rival products. Several indicators suggest that these benefits are very large. 65\% of the world's 25 most valuable public companies are technology companies, and $82 \%$ of the total market capitalisation of these companies consists of US tech firms (Forbes, 2019). In addition, 55\% of US 'unicorns' (start-ups worth $\$ 1$ billion or more) were founded by immigrant entrepreneurs and more than $80 \%$ of these companies also had immigrants as key managers (Anderson, 2018). Such connections provide US companies with an unparalleled edge in penetrating global markets. The US benefits especially well from new technology markets - including those in information technology and biotechnology - since these often have winner-take-all profit distributions. Strong US capital markets reinforce these advantages and attract venture capital from across the world.

Regrettably, aside from rare exceptions such as Clausing (2019), the general US public discussion does not fully recognise these benefits. Yet it would be difficult to imagine life in the US without imported food, steel, garments, electronics, or cars. Equally, highly productive US firms such as JP Morgan, Boeing, Intel, Facebook, and Johnson \& Johnson could not easily replace export markets for airplanes, online platforms, pharmaceuticals, financial products, movies, higher education, or agricultural products. Precisely because trade is so ubiquitous, the debate takes its positive effects for granted. Few US consumers fully appreciate how imports affect what they spend and exports affect where they work. At the same time, those who experience job losses, whether due to automation or trade, see very personal costs. As theory anticipates, the debate focuses primarily on those costs.

\section{Globalisation and labour market effects}

Labour market effects, which have dominated recent critiques of globalisation in the US, focus on unemployment, wage inequality, and other concerns such as low labour force participation rates. Some critics argue that more trade, say due to trade liberalisation, causes trade deficits, which in turn cause unemployment. Some studies find significant impacts from trade on unemployment under specific circumstances, such as large, rapidly emerging threats for declining industries in some localities. However, there is no convincing evidence that trade increases unemployment in a long-term, economy-wide context.

Other critics focus on the effects of low-wage competition on wage growth and wage inequality in the US. There is considerable evidence that wage inequality has increased over time, but the causes are less clear. Trade may have contributed to increased inequality - as a high-wage country, the US tends to import products from countries with lower wages - but the evidence mainly points to technological change rather than import competition as the source of pressure. Nevertheless, given the implications of inequality, there is an urgent 
need for understanding the mechanisms that account for it and countering their effects. The gains from trade likely exceed - potentially by orders of magnitude the costs of fighting inequality attributable to trade, but unfortunately effective policies have yet to be deployed.

\subsection{Unemployment}

The simplest and most frequent argument made is that globalisation, i.e. keeping US markets open, has created trade deficits which in turn have led to US job losses. To President Trump and others, the case is self-evident: imports replace jobs while exports create them. As the US opened its markets, its trade deficits rose as other countries 'stole' its jobs.

However, there is no logical link between economic openness and a trade deficit, or between a trade deficit and unemployment. Trade deficits are determined by the excess of national savings over investment. Unless a trade shock - say, tariff reductions - affects these variables, ${ }^{2}$ the deficit will not change. (For example, even if imports decrease, other adjustments will lead to a similar fall in exports.) Even when trade deficits change, employment tends to be unaffected. Employment is determined by demographic and macroeconomic forces that automatically, or sometimes with a nudge from policy, restore normal employment levels.

In fact, high trade deficits usually correlate with low unemployment (Figure 8.3). This is not a causal relationship - changes in both variables are due to changes in economic activity. A strong economy generates investment demand by more than it increases savings - and thus generates labour market pressures that reduce unemployment. That is why, given continuing robust economic growth, the US trade deficit has grown by $24 \%$, from $\$ 502$ billion in 2016 to $\$ 622$ billion in 2018 (US Census Bureau, 2019), while unemployment has fallen to record levels, despite unprecedented tariffs mistakenly imposed to reduce the trade deficit.

Nevertheless, some studies have suggested long-lived unemployment in specific locations because of unusual trade shocks. Autor and colleagues (2013b, 2016, reviewed in detail below) found serious and persistent consequences from some trade shocks as they interact with multiplier effects in local economies. In those cases, production displaced by imports results in additional job losses in local firms which depend on selling their goods to displaced manufacturers and their workers. Because these effects reinforce the trade shocks, adjustment is slow and costly. Such costs are concentrated in communities where adjustment options are limited.

\subsection{Wage inequality}

Americans have come to believe the social contract underlying the US marketoriented economic system: hard work will generate steady improvements in the standard of living. However, the data suggest that this expectation is no longer reliably met. Household incomes have grown substantially only at the top, and 


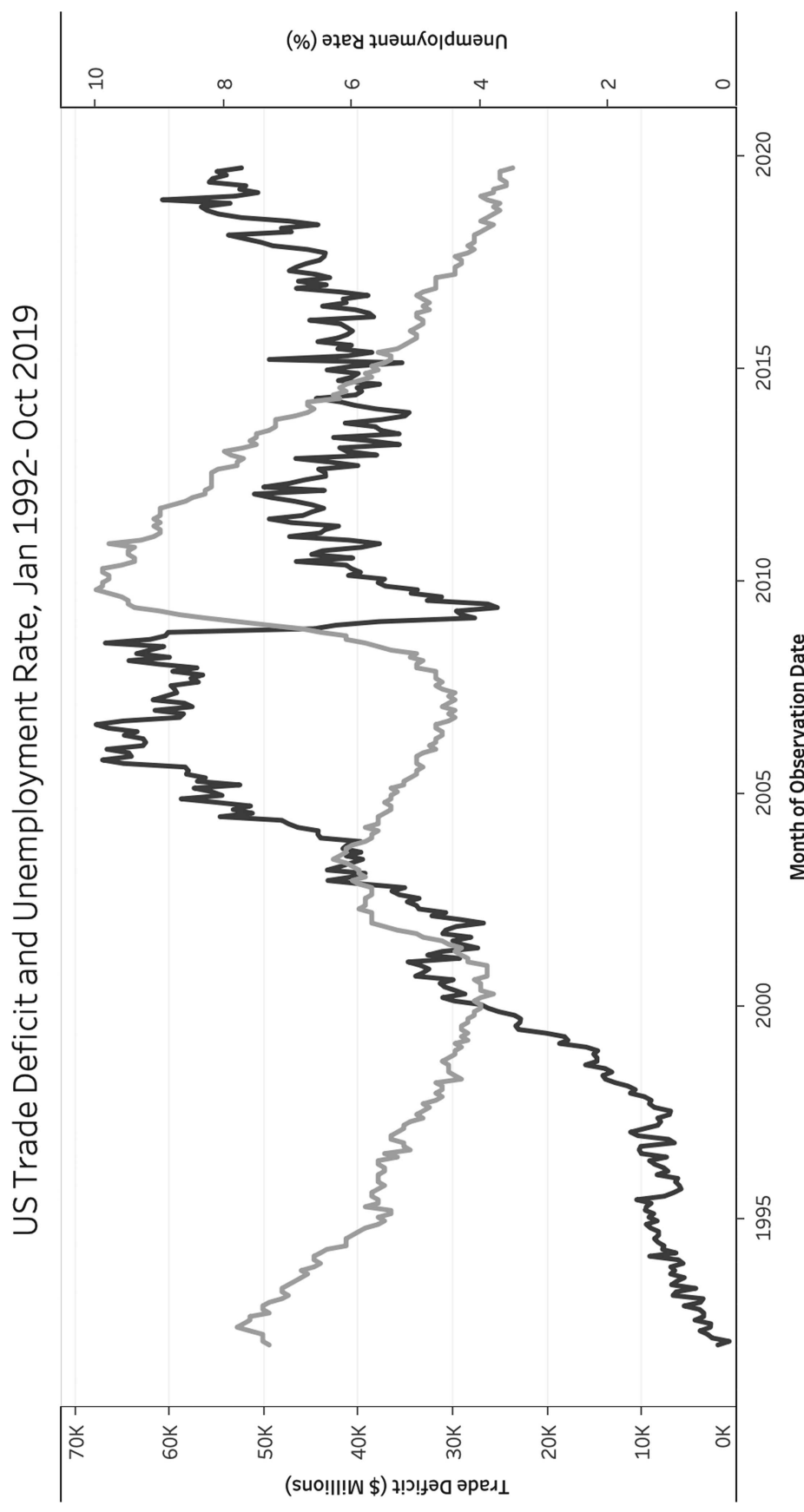

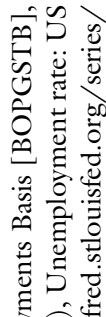

会进

पै요

这

氜

ค.

s。

矛苍

氖

莀

- 000

의

论

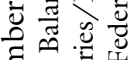

可式

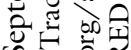

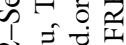

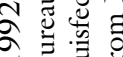

حิ

눌

节苛.

至U进焉

ثै?

正击

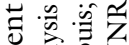

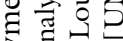

을. 㫕

ฮี

可 节

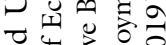

낭

.ت

过苛要

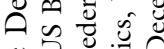

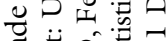

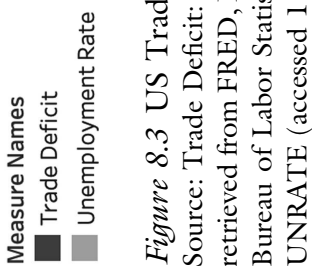


real wages for many workers have stagnated for decades. Figure 8.4 shows starkly divergent trends for wages sorted by education, which diverge especially significantly for male workers (Autor, 2014). Male workers with a post-college education saw their real wages rise in the last four decades. Those with just a college education earned about the same real wage in 2012 as in 1973, and those with less-than-college education generally earned less.

The data leave little doubt that wage inequality is increasing. Inequality is also increasing amongst women, but they have generally done better than men in recent decades. These trends appear to date back to the 1970s, at about the beginning of the rise of global interdependence, but well before the recent emergence of China as a major trading power. Over time, they have cumulatively led to large wage gaps and increasing political concern. As explored below, the mechanisms driving wage inequality could include trade, technological change, and trends in the structure of demand.

\subsection{Declining labour force participation and other effects}

The slow recovery of US employment after the global financial crisis was due in part to a decline in labour force participation after 2008. A popular explanation

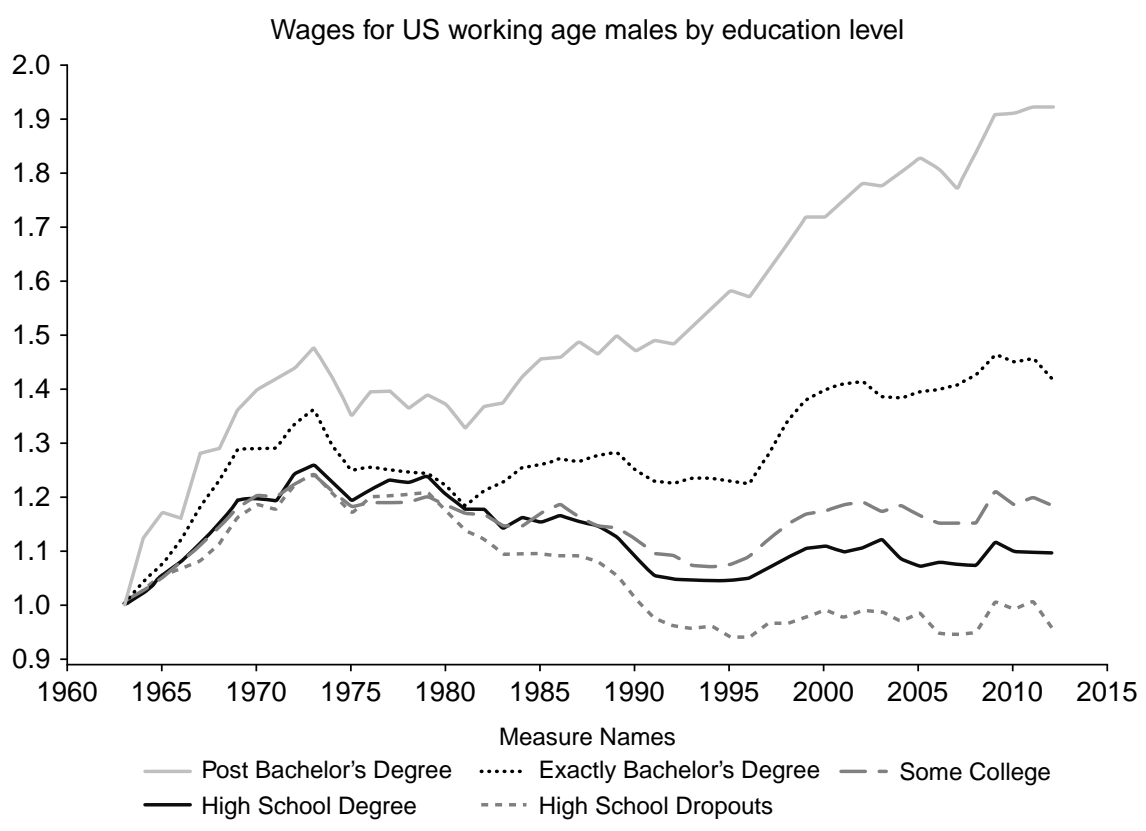

Figure 8.4 Wages for US Working Age Males by Education Level.

Source: Autor (2014).

Note: Based on weekly earnings data from the US Current Population Survey for working age adults who worked at least one week during the year. 
was that stagnating wages at the low end of the distribution discouraged workers from re-entering the labour force even when jobs became available. Diminished labour force participation is partly explained by population aging and the end of a sharp rise in women entering the workforce. In 2018 and 2019, labour force participation rates have begun to rise again, without a significant narrowing of wage gaps. This suggests that pure market demand for labour, rather than growing wage gaps, was the principal driver of participation trends. Sustained growth in demand appears to draw even marginal workers back into the labour force.

In popular discussion, bleak wage and job quality trends are also often linked to dramatic declines in the well-being of some US workers. In a widely cited study, Case and Deaton (2017) found that increases in all-cause mortality rates rose steadily from 1998 to 2015 - a period roughly coinciding with the labour market effects considered here - for white, non-Hispanic Americans without a college degree. These rates included increases in drug overdoses, suicides, and alcohol-related disease. Yet direct links to labour market results are very difficult to find - the authors could not find statistical connections between contemporaneous resources, stagnating incomes, and mortality. They instead proposed that explanations lie in cumulative disadvantages - in labour market, health, and other outcomes - from one birth cohort to the next. They believe that these disadvantages may have been building steadily for whites with low education levels, leading to current mortality trends.

\subsection{Mechanisms which cause inequality}

Given the important social and economic role of wage inequality, we next examine the potential drivers of recent trends, including trade, technological change, and changes in product demand. We review major mechanisms that appear to be driving wage inequality as a step towards understanding the role of globalisation as a cause.

Trade and offshoring. There are good reasons to expect that trade will increase wage inequality. Since the US has plentiful endowments of capital relative to labour, increased trade generally raises the return to capital and lowers the return to labour. Since capital includes human capital, the wages of educated workers may then rise relative to those with limited skills. In addition to trade, offshoring - the relocation of production abroad by domestic firms - has been specifically blamed for adverse labour market effects, since domestic firms may be more effective than foreign firms in producing abroad to exploit endowment differences. Improved logistics and communications also enable companies to break production into smaller tasks and import a growing share of components from abroad. For example, car manufacturers have increasingly lengthy supply chains that typically include locating significant parts of production abroad.

Technological change. Research on technological change has focused on the possibility of job polarisation - the growth of low- and high-skilled jobs coupled with a decline in middle-skilled jobs (Goos and Manning, 2003). The result may be a loss of careers that once provided reasonable incomes without a college-level 
education. Traditional manufacturing is one source of such jobs and explains the preoccupation of President Trump and other policymakers with aiding the manufacturing sector. There is indeed evidence of polarisation, but its causes could include several drivers.

Autor (2014) noted that tasks which are difficult to automate are those that demand flexibility, judgment, and common sense. These include two categories: 'abstract' tasks that require extensive problem solving and include professional, technical, and managerial occupations; and 'manual' tasks that require situational adaptability and personal interactions, which include service jobs such as food preparation and health assistance. While these types of jobs are relatively safe from automation, middle-skilled jobs with routine tasks are often exposed. Figure 8.5 shows that, from 1979 to 2012, changes in the occupational distribution did support the polarisation hypothesis. The decline in middle-skilled jobs was especially significant in the 2007-12 sub-period.

Trade or offshoring may aggravate this polarised pattern. The production of tradable products, such as manufactures, tends to require high-skilled or middleskilled jobs. For an advanced economy, such as that of the US, this means increasing high-skilled employment for sophisticated export industries and reducing middle-skilled employment in less sophisticated import-competing industries. Meanwhile, as the share of demand grows in non-tradable service industries, demand will increase in low-wage service occupations. Thus, the polarising effect of technological change on job markets is reinforced by trade specialisation in sophisticated products.

Superstars. Data show that the wages of the highest paid workers have risen especially fast in the US. This may be because workers at the high end of the distribution are generally well educated, but the correspondence is not perfect Mark Zuckerberg, Bill Gates, and Jan Koum all failed to finish college. Highly compensated workers may be successful less because of their education and more because they become 'superstars' in markets that produce 'winner take all' returns (Rosen, 1981).

In winner-take-all sectors, best performers may be only slightly more productive than the next best, but will still capture a large share of total returns. Some examples include sports and entertainment stars, as well as senior managers of large corporations. Superstar markets emerge with technologies that expand the scale of markets, as for example through wide access to audio or video broadcasts. Superstar markets may also emerge when scale economies or network externalities eliminate competition - for example, in retail markets such as those dominated by Walmart or Amazon.

Although the earnings of superstars are rooted in technology, inequality is aggravated by the large markets created by international economic integration. Ebenstein, Harrison, and McMillan (2015) argued that superstar effects originate not in ordinary channels of trade, but in new channels that reflect the improved tradability of services. They found little evidence for classic channels of globalisation in goods and services in superstar returns - it is the interplay of 


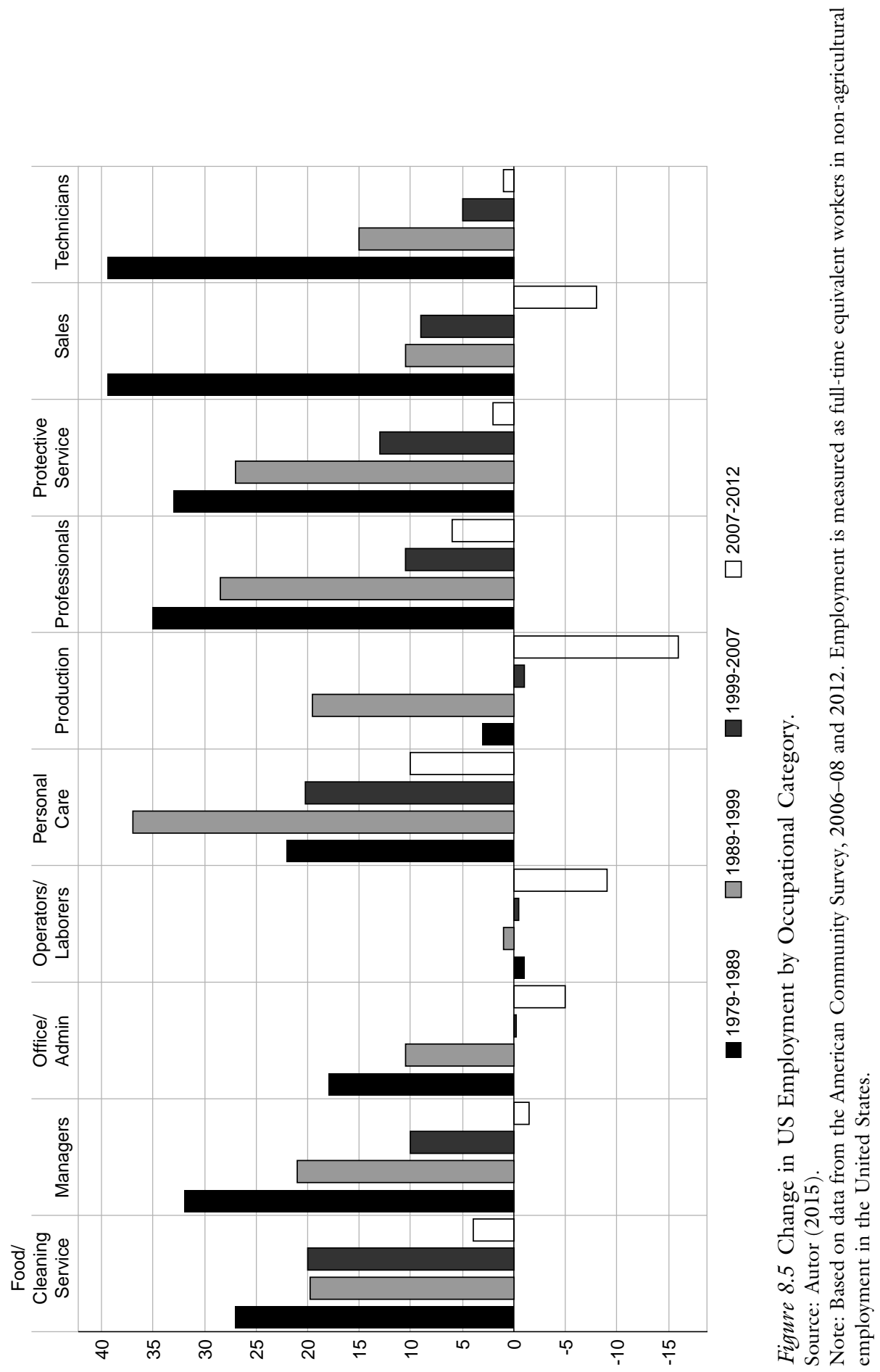


technologies and market sizes (made possible by economic integration) that explains dramatically rising wage differentials in some occupations and industries.

\subsection{Is globalisation to blame?}

Few estimates are available for separating the relative importance of trade and productivity effects. One recent study of the decline in US manufacturing employment suggested that technological changes have been much more important (Hicks and Deveraj, 2017). Table 8.1 shows that total manufacturing employment declined by 5,647,700 workers from 2000 to 2010 . Net import increases explained $13.4 \%$ of this change, while productivity improvements accounted for $87.8 \%$. (Together, these causes explained $101.2 \%$ of job losses; the extra $1.2 \%$ is due to jobs created by an increase in demand.) Thus, the shares of trade and technology were $13.2 \%(=13.4 / 101.2)$ and $86.8 \%(=87.4 / 101.2)$, respectively, of manufacturing job losses from 2000 to 2010. This was when US net imports were rising rapidly due to China's accession to the World Trade Organization (WTO) and the explosion of the US trade deficit. While no similar calculations are available for wage inequality, one might expect effects on those measures to be broadly similar.

Econometric evidence on how trade policy affects wage inequality is sparse. A review of seven studies by Deardorff and Hakura (1994) reported that the effects of liberalisation episodes on the wage distribution ranged from substantial to nil. Slaughter (1998) reviewed nine additional studies and also reached mixed conclusions. Recent work (Haskel et al., 2012) has continued to find mixed results. A third study by Baldwin and Cain (2000) used a general equilibrium approach to analyse how changes in trade affect wages, and found that trade alone could not account for observed wage inequality effects. They argued that growing inequality must be the result of alternative forces, including education-biased technical change, and a growing supply of educated labour compared with unskilled labour.

Ebenstein, Harrison, and McMillan (2015) found, however, that globalisation may have significantly affected US wage inequality. They argued that previous studies missed this effect because they examined wage differentials across industries rather than occupations. They viewed a worker's occupation as the locus of exposure to international competition, since it is harder for workers to switch occupations than industries (Kambourov and Manovskii, 2009a, 2009b). They therefore regressed wages on measures of offshoring and trade with annual data from 1983 to 2008 . They first ran regressions for wages on offshoring and trade for various industrial sectors. They then repeated the analysis using various occupations and found that these regressions do not fit nearly as well for industries as they do for occupations. In sector regressions, the offshoring and trade coefficients were typically close to zero and insignificant, while in occupational regressions they were larger and generally significant with the expected sign. Further, they found that exposure to offshoring and trade with high-income 
Table 8.1 Trade and Productivity Effects in Manufacturing

\begin{tabular}{|c|c|c|c|c|c|}
\hline Sector & $\begin{array}{l}\text { Production } \\
\text { Change per } \\
\text { Worker }\end{array}$ & $\begin{array}{l}\text { Actual Job } \\
\text { Losses }\end{array}$ & $\begin{array}{l}\text { Job } \\
\text { Losses } \\
\text { due to } \\
\text { Trade }\end{array}$ & $\begin{array}{l}\text { Job Losses } \\
\text { due to } \\
\text { Productivity }\end{array}$ & $\begin{array}{l}\text { Job Gains } \\
\text { due to } \\
\text { Demand }\end{array}$ \\
\hline $\begin{array}{l}\text { All } \\
\text { manufacturing }\end{array}$ & $67.5 \%$ & $5,647,700$ & $13.4 \%$ & $87.8 \%$ & $1.2 \%$ \\
\hline $\begin{array}{l}\text { Durable goods } \\
\text { manufacturing }\end{array}$ & $82.9 \%$ & $3,737,200$ & $12.3 \%$ & $88.2 \%$ & $0.5 \%$ \\
\hline Wood products & $47.0 \%$ & 274,900 & $14.4 \%$ & $81.9 \%$ & $-3.6 \%$ \\
\hline $\begin{array}{l}\text { Non-metallic } \\
\text { mineral } \\
\text { products }\end{array}$ & $6.5 \%$ & 177,000 & $12.8 \%$ & $90.4 \%$ & $3.2 \%$ \\
\hline Primary metals & $39.1 \%$ & 248,500 & $-3.3 \%$ & $76.7 \%$ & $-26.7 \%$ \\
\hline $\begin{array}{l}\text { Fabricated metal } \\
\text { products }\end{array}$ & $8.9 \%$ & 478,200 & $6.9 \%$ & $97.7 \%$ & $4.5 \%$ \\
\hline Machinery & $39.9 \%$ & 447,400 & $0.8 \%$ & $99.6 \%$ & $0.4 \%$ \\
\hline $\begin{array}{l}\text { Computer and } \\
\text { electronic } \\
\text { products }\end{array}$ & $350.3 \%$ & 694 & $18.8 \%$ & $117.7 \%$ & $36.5 \%$ \\
\hline $\begin{array}{l}\text { Electrical } \\
\text { equipment, } \\
\text { appliances, and } \\
\text { components }\end{array}$ & $57.3 \%$ & 233,700 & $19.0 \%$ & $88.1 \%$ & $7.1 \%$ \\
\hline $\begin{array}{l}\text { Transportation } \\
\text { and motor } \\
\text { vehicles }\end{array}$ & $64.1 \%$ & 716,500 & $5.5 \%$ & $85.5 \%$ & $-9.0 \%$ \\
\hline $\begin{array}{l}\text { Furniture and } \\
\text { related } \\
\text { products }\end{array}$ & $5.6 \%$ & 327,700 & $40.2 \%$ & $81.1 \%$ & $21.3 \%$ \\
\hline $\begin{array}{l}\text { Miscellaneous } \\
\text { manufacturing }\end{array}$ & $62.2 \%$ & 140 & $21.7 \%$ & $76.7 \%$ & $-1.6 \%$ \\
\hline $\begin{array}{l}\text { Non-durable } \\
\text { goods } \\
\text { manufacturing }\end{array}$ & $48.5 \%$ & $1,910,500$ & $12.3 \%$ & $90.0 \%$ & $2.3 \%$ \\
\hline $\begin{array}{l}\text { Food and } \\
\text { beverage and } \\
\text { tobacco } \\
\text { products }\end{array}$ & $23.1 \%$ & 119,200 & $4.3 \%$ & $96.8 \%$ & $1.1 \%$ \\
\hline $\begin{array}{l}\text { Textile and } \\
\text { textile product } \\
\text { mills }\end{array}$ & $22.4 \%$ & 345,200 & $9.5 \%$ & $97.6 \%$ & $7.0 \%$ \\
\hline $\begin{array}{l}\text { Apparel, leather, } \\
\text { and allied } \\
\text { products }\end{array}$ & $45.9 \%$ & 370,500 & $44.6 \%$ & $58.5 \%$ & $3.1 \%$ \\
\hline Paper products & $13.0 \%$ & 210,300 & $1.7 \%$ & $93.2 \%$ & $-5.0 \%$ \\
\hline $\begin{array}{l}\text { Printing and } \\
\text { related } \\
\text { activities }\end{array}$ & $54.1 \%$ & 319 & $-2.1 \%$ & $101.8 \%$ & $-0.3 \%$ \\
\hline $\begin{array}{l}\text { Petroleum and } \\
\text { coal products }\end{array}$ & $41.0 \%$ & 9,100 & $13.3 \%$ & $77.1 \%$ & $-9.6 \%$ \\
\hline
\end{tabular}


Table 8.1 (Continued)

\begin{tabular}{lccccc}
\hline Sector & $\begin{array}{l}\text { Production } \\
\text { Change per } \\
\text { Worker }\end{array}$ & $\begin{array}{l}\text { Actual Job } \\
\text { Losses }\end{array}$ & $\begin{array}{l}\text { Job } \\
\text { Losses } \\
\text { due to } \\
\text { Trade }\end{array}$ & $\begin{array}{l}\text { Job Losses } \\
\text { due to } \\
\text { Productivity }\end{array}$ & $\begin{array}{l}\text { Job Gains } \\
\text { due to } \\
\text { Demand }\end{array}$ \\
\hline $\begin{array}{c}\text { Chemical } \\
\text { products }\end{array}$ & $52.8 \%$ & 186,500 & $1.4 \%$ & $101.1 \%$ & $2.5 \%$ \\
$\begin{array}{c}\text { Plastics and } \\
\text { rubber } \\
\text { products }\end{array}$ & $30.4 \%$ & 351,100 & $7.4 \%$ & $100.5 \%$ & $7.9 \%$ \\
\hline
\end{tabular}

Source: Hicks and Deveraj (2017).

Notes: Based on calculations from United States Census Bureau. Motor vehicles and transportation sectors are aggregated because of incomplete data.

partners raises an occupation's wages, while exposure and trade with low-income partners depresses wages.

Ebenstein, Harrison, and McMillan (2015) also studied labour force participation. They hypothesised that people who worked in the 'glory days' of US manufacturing would find wages depressed due to globalisation and would not find them attractive enough to stay in the labour force. Their regressions, however, did not show reduced labour force participation. Only exposure to offshoring to China had the expected negative effect - perhaps because it was a larger and more sudden shock. They also found that technological factors, including the use of computers and capital intensity, were significantly associated with declining labour force participation.

In summary, the evidence suggests that technological change had a much larger effect on employment in different industry sectors than globalisation. However, studies which attempt to tease out the relative effects of these drivers on wage inequality have shown mixed results.

\section{The effects of trade policy changes}

Most trade deals involve political controversy in the US, typically pitting labouroriented Democrats against business-oriented Republicans. In the usual resolution, a centrist wing of the Democratic party sides with Republicans to ensure the passage of an agreement. This was the case with the Uruguay Round agreement; NAFTA; the granting of PNTR to China; and bilateral trade agreements with Chile, the Republic of Korea (henceforth, Korea), and Colombia, amongst others. More recently, however, this calculus has been upended by the shift in the position of the Republican party under President Trump, perhaps to court older, white workers in the centre of the country who have been historically employed in manufacturing. This new anti-trade faction has made it unusually difficult to defend the traditionally liberal trade policies of the US. 
Controversies over old agreements have also resurrected. Two significant agreements are prominent in the debate: NAFTA (which the President renegotiated as the US-Mexico-Canada Agreement) and PNTR for China. President Trump has indicated his displeasure with both.

\subsection{NAFTA}

Although NAFTA has been in effect for a quarter century, estimates of its benefits are difficult to pinpoint since the economic results of NAFTA countries are attributable to many forces. However, trade amongst NAFTA countries has increased substantially, suggesting greater specialisation and the development of more competitive industries in each country.

Caliendo and Parro (2015) estimated the benefits of NAFTA with a rigorous modern empirical model. They found welfare increases of $0.08 \%$ for the US, $1.31 \%$ for Mexico, and $-0.06 \%$ for Canada. When applied to 2018 GDP levels, these ratios represent annual gains of $\$ 16.4$ billion, $\$ 15.2$ billion, and $-\$ 1.0$ billion for the three countries. (Canada had a free trade agreement with the US before NAFTA, so its losses with NAFTA may represent trade diversion to Mexico.) However, these estimates are likely to be too low, since they only considered tariff changes and ignored other important changes in non-tariff barriers and the certainty of regional trade and investment rules.

Hufbauer, Cimino-Isaacs, and Moran (2014) provided theoretically less rigorous but empirically very thorough estimates based on increased trade amongst NAFTA economies. They calculated the incremental trade effect as actual post-NAFTA trade minus trade that would have taken place due to GDP growth alone. They then calculated welfare gains as a share of trade gains, finding annual gains of $\$ 127$ billion for the US, $\$ 170$ billion for Mexico, and $\$ 50$ billion for Canada. These estimates are likely too high, since only a fraction of trade growth beyond GDP-related growth can be attributed to NAFTA. Hufbauer, Cimino-Isaacs, and Moran (2014) also noted the following:

- The shift in bilateral trade between Mexico and the US - from a $\$ 5$ billion surplus in 1994 to a $\$ 45$ billion deficit in 2013 - cannot be attributed to NAFTA, since it was the result of greater US energy imports due to the changing energy position of the US, and large opposite shifts in the Mexican and US global trade deficits.

- Only $5 \%$ of US job dislocations in the years following NAFTA can be attributed to NAFTA; of these workers, only one-fifth became unemployed and eligible for Trade Adjustment Assistance. Nevertheless, NAFTA was a small part of the US job churn, ${ }^{3}$ which typically involves 4 million US workers every year.

- Trade with Mexico likely increased, rather than depressed, US wages, given observations on wages paid in newly created export jobs and jobs replaced by 
import competition. US firms also became more competitive vis-à-vis third countries.

In addition, NAFTA had important political objectives. The US wanted a positive partnership with its largest neighbour; corruption and leftist ideologies had long marred this relationship. Mexico's political system gradually modernised and its relations with the US improved. Polling has shown that the share of Mexicans trusting the US more than doubled from 2004 to 2016, and then collapsed abruptly after President Trump took office (Las Américas y el Mundo (n.d.) survey conducted by the Centro de Investigación y Docencia Económicas (CIDE)).

The US also wanted to stimulate Mexican development to reduce disparities that caused political tensions and immigration pressures. For a variety of reasons that have little to do with trade policy, NAFTA did not succeed in substantially accelerating Mexican growth, but progress was made on modernising the Mexican economy. Meanwhile, immigration decreased substantially, with the apprehension of illegal migrants on the US southern border falling from 1.6 million per year in 2000 to about 400,000 in 2018 (US Customs and Border Protection, n.d.). This falloff had multiple causes, including changes in Mexican demographics, rising US unemployment, and improved border controls.

NAFTA increased the interdependence of its members and thus had positive effects on the region's economy. There is little evidence that it affected US labour markets negatively, and it almost certainly helped to improve US-Mexico relations. Auto industry representatives are especially supportive, arguing that diverse regional production capabilities made the US much more competitive with Japan, Korea, and potentially China in the long run.

\subsection{Permanent normal trade relations with China}

The effects of the US conferral of PNTR on China and its subsequent accession to the WTO in 2001, frequently described as the 'China shock' in the research literature, are more ambiguous. PNTR did not change the tariffs applied by the US to Chinese goods, since US imports from China had been subject to normal tariffs reserved for WTO members since the 1980s. However, China's normal trade relations rates had to be renewed annually in an uncertain and politically contentious process. Without renewal, tariffs would have jumped to high rates set by the Smoot-Hawley Tariff Act of 1930. PNTR reduced uncertainty for Chinese exporters serving the US.

The importance of PNTR is confirmed by the growth of US-China trade: from 2000 to 2007, Chinese exports to the US increased from $\$ 122$ billion to $\$ 330$ billion, at an average rate of $15 \%$ per year (US International Trade Commission, 2019). This increase explains a substantial part of the globalisation benefits estimated in Section II. In addition, China's entry into mainstream world markets led to a greater reliance on markets at home and a larger role in 
the international governance system. Until relatively recently, PNTR was viewed as a critical step in paving the way to the fuller integration of China in the world economic system.

The implications for US labour markets are framed by two research contributions. Pierce and Schott (2014) examined the growth of US imports from China after China's admission to the WTO, based on the hypothesis that these increases reflect the reduction in uncertainty over tariffs. Autor, Dorn, and Hansen (2013b) examined the effects of import increases on employment and wages in the localities exposed to imports. Their main findings are that local labour market effects are substantial and persistent.

Pierce and Schott (2014) used the gap between the Smooth-Hawley tariffs and the PNTR rates as a measure of the uncertainty that China's accession to the WTO eliminated. This tariff gap is large: in 1999, US PNTR tariffs averaged $4 \%$ while non-PNTR tariffs averaged $36 \%$. The authors showed that in sectors where the tariff gap was initially large, and hence uncertainty was sharply reduced by the PNTR, US imports increased and US employment decreased. They further confirmed the causal role of PNTR by showing that pre- and post-PNTR trade evolved quite differently in high-tariff-gap and low-tariff-gap industries. After PNTR, employment fell sharply in high-tariff-gap industries, but remained relatively constant in low-tariff-gap industries.

Pierce and Schott (2014) also concluded that PNTR was an unexpected shock: it mattered for trade and employment, yet its effects could not be detected significantly before China was admitted to the WTO (using data with annual frequency). This finding is consistent with Autor et al. (2103b), using the 'China shock' as an explanatory variable in analysing the effects of imports.

The most influential contributions to the employment debate have come from Autor and colleagues $(2013 \mathrm{~b}, 2016)$ who argued that the economics profession has seriously underestimated the difficulty of adjusting to trade shocks. Their econometric approach focused on the surge in US imports from China following PNTR, and estimated the response of different US 'commuting zones ${ }^{4}$ to exposure to imports from China over several decades. Exposure was measured using data on the sectoral structure of a commuting zone and on corresponding imports from China, using an instrumental variable to represent the import shock in each commuting zone.

The central regressions show how several labour market variables react to the exposure of commuting zones to imports from China. The results show that a $\$ 1,000 /$ worker increase in a commuting zone's exposure reduces its employment by $0.75 \%$. Additional controls (the share of manufacturing in commuting zone employment and the share of routine occupations in employment) in this equation matter, but only reduce the employment effect by one-third. In addition, a commuting zone's exposure to the China shock does not lead to significant out-migration, but it does lead to both unemployment (about one-quarter of the effect) and lower labour force participation (about three-quarters of the effect). Somewhat surprisingly, wage regressions show no significant changes in manufacturing wages due to exposure, and 
decline only in non-manufacturing sectors. Finally, exposure raises the commuting zone's government transfer payments and reduces its household income.

An important criticism of the work of Autor and his colleagues is that it focuses only on imports, even though PNTR is also likely to have increased incentives for US firms to export to China and other markets. These activities will have generated jobs. However, since these endogenous export effects are not related to the import exposure of a commuting zone, they do not show up in the regression results of Autor and colleagues.

Feenstra and Sasahara (2017) used a methodology like Autor, Dorn, and Hanson (2013b) to add export exposure effects to the regression analysis. Applying their coefficients to actual trade values in 1991-2011, they found that import exposure resulted in about 4.22 million job losses for the US as a whole, while export exposure generated about 4.24 million job gains. Although US manufacturing experienced significant employment losses during this period, they concluded that this was associated with factors such as technological progress rather than trade. The results suggest a somewhat unexpected positive geographic correlation between import losses and export gains: commuting zones with high percentages of employment losses due to imports are also likely to have a higher percentage of employment gains due to exports. This explains how local labour markets reached equilibrium even in the absence of strong mobility across regions. However, this correlation weakened in the more recent decade of their analysis (2001-11).

In sum, ex-post studies of trade policy changes offer several results. Criticisms of NAFTA (unemployment in the US, wage depression, and illegal immigration) do not appear justified. Some large predicted adjustments, including the predicted 'giant sucking sound' Some large predicted benefits also failed to materialise, especially an acceleration of Mexican growth. Benefits on a more modest scale appear to have been realised, however, and NAFTA probably made US manufacturing more competitive by giving it better access to the North American production base. The case of PNTR for China produces more mixed evidence. Overall welfare gains were probably substantial, but some negative labour market effects may have been underestimated.

\section{Concluding remarks}

Globalisation has accelerated in recent decades and has had a large, positive impact on the US, the world economy, and many developing countries. At the same time, globalisation has faced intense criticism for adverse side-effects on employment and wages. Interestingly, in the US, both the political left and right claim focus on these negative results. The studies reviewed in this paper offer empirical evidence on these issues, but even more importantly confirm the large benefits associated with trade.

Nevertheless, the economic as well as political costs of worsening distributional trends are substantial and demand urgent solutions. These solutions will have to be based on creative and sophisticated ways of mitigating adverse trends. Even if 
technological change and international economic integration have 'caused' adverse labour market trends, it does not follow that the erection of barriers against them is a useful solution.

The drivers of economic progress - technological innovations; falling communication and transport costs; new opportunities to connect ideas, investments, and markets - have yielded large benefits in the past and will likely continue to do so in the future. Even if trade growth slows, the economic forces connecting countries are not likely to retreat. Meanwhile, technological change seems to be accelerating. In this period of rapid change, economic shocks and policy confusion are inevitable. The critical challenge is to sustain the positive aspects of economic change while designing policies to overcome its negative side-effects.

\section{Notes}

1 This calculation assumes that gains are proportional to changes in the share of trade in US GDP. This ratio increased from $10.7 \%$ in 1947 to $22.4 \%$ in 2003 and $27.8 \%$ in 2018. Thus, the incremental gain from 1947 to 2018 was $17.1 / 10.7=1.46$ times that of the gain from 1947 to 2003 . These results are further scaled by the ratio of 2018 to 2003 GDP (=1.87).

2 This discussion abstracts from possible short-run, transitional links between trade shocks and savings.

3 The turnover in firms' staff as existing employees leave and new ones are hired.

4 A commuting zone is a geographic area used in population and economic analysis.

5 US presidential candidate Ross Perot's phrase for what he believed would be the negative effects of NAFTA.

\section{References}

Amiti, M. and S.-J. Wei (2009), 'Service Offshoring and Productivity: Evidence from the US', The World Economy, 32(2), pp.203-220.

Anderson, S. (2018), 'Immigrants and Billion-Dollar Companies', NFAP Policy Brief. Washington: National Foundation for American Policy.

Autor, D. (2014), 'Skills, Education, and the Rise of Earnings Inequality Among the “Other 99 Percent"', Science, 344(6186), pp.843-851.

Autor, D. (2015), 'Why Are There Still So Many Jobs? The History and Future of Workplace Automation', Journal of Economic Perspectives, 29(3), pp.3-30.

Autor, D.H., D. Dorn, and G.H. Hanson (2013a), 'Untangling Trade and Technology: Evidence from Local Labor Markets', NBER Working Paper Series, No. 18938. Cambridge, MA: National Bureau of Economic Research.

Autor, D.H., D. Dorn, and G.H. Hanson (2013b), 'The China Syndrome: Local Labor Market Effects of Import Competition in the United States', American Economic Review, 103(6), pp.2121-2168.

Autor, D., D. Dorn, and G.H. Hanson (2016), 'The China Shock: Learning from Labor Market Adjustment to Large Changes in Trade', IZA Discussion Paper Series, No. 9748. Bonn: Institute for the Study of Labor (IZA).

Baldwin, R.E. and G.G. Cain (2000), 'Shifts in U.S. Relative Wages: The Role of Trade, Technology, and Factor Endowments', The Review of Economics and Statistics, 82(4), pp.580-595. 


\section{Peter A. Petri and Meenal Banga}

Bernard, A.B., J. Eaton, J.B. Jensen, and S. Kortum (2003), 'Plants and Productivity in International Trade', American Economic Review, 93(4), pp.1268-1290.

Bradford, S.C., P.L.E. Grieco, and G.C. Hufbauer (2005), 'The Payoff to America from Global Integration', in C.F. Bergsten (ed.), The United States and the World Economy: Foreign Economic Policy for the Next Decade. Washington, DC: Peterson Institute for International Economics, pp.65-109.

Caliendo L. and F. Parro (2015), 'Estimates of the Trade and Welfare Effects of NAFTA', The Review of Economic Studies, 82(1), pp.1-44.

Case, A. and A. Deaton (2017), 'Mortality and Morbidity in the 2lst Century', Brookings Papers on Economic Activity, 82(1, Spring), pp.397-443.

Clausing, K. (2019), 'The Progressive Case Against Protectionism: How Trade and Immigration Help American Workers', Foreign Affairs, 98(6), pp.109-121, November/December.

Constantinescu, C., A. Mattoo, and M. Ruta (2019), 'Does Vertical Specialisation Increase Productivity?', The World Economy, 42(8), pp.2385-2402.

Deardorff, A.V. and D.S. Hakura (1994), 'Trade and Wages - What Are the Questions?', in J. Bhagwati and M. Kosters (eds.), Trade and Wages: Leveling Wages Down? Washington, DC: American Enterprise Institute Press, pp.76-107.

Ebenstein, A., A. Harrison, and M. McMillan (2015), 'Why Are American Workers Getting Poorer? China, Trade and Offshoring', NBER Working Paper Series, No. 21027. Cambridge, MA: National Bureau of Economic Research.

Federico, G. and A. Tena-Junguito (2016), 'A Tale of Two Globalizations: Gains from Trade and Openness 1800-2010', CEPR Discussion Papers, No. 11128. London: Centre for Economic Policy Research.

Feenstra, R.C. and A. Sasahara (2017), "The "China Shock", Exports and U.S. Employment: A Global Input-Output Analysis', NBER Working Paper Series, No. 24022. Cambridge, MA: National Bureau of Economic Research.

Forbes (2019), 'The World's Largest Public Companies'. Available at: https:// www.forbes.com/global2000/list/ (accessed 25October2019).

Formai, S. and F. Vergara Caffarelli (2016), 'Quantifying the Productivity Effects of Global Sourcing', Bank of Italy Working Papers, No. 1075. Rome: Bank of Italy.

Fouquin, M. and J. Hugot (2016), 'Back to the Future: International Trade Costs and the Two Globalizations', CEPII Working Paper, No. 13. Paris: Centre d'études prospectives et d'informations internationales (CEPII).

Goos, M. and A. Manning (2003), 'Lousy and Lovely Jobs: The Rising Polarization of Work in Britain', The Review of Economics and Statistics, 89(1), pp.118-133.

Haskel, J., R.Z. Lawrence, E.E. Leamer, and M.J. Slaughter (2012), 'Globalization and U.S. Wages: Modifying Classic Theory to Explain Recent Facts', Journal of Economic Perspectives, 26(2), pp.119-140.

Hicks, M.J. and S. Deveraj (2017), The Myth and the Reality of Manufacturing in America. Muncie, IN: Ball State University Center for Business and Economic Research.

Hufbauer, G.C., C. Cimino-Isaacs, and T. Moran (2014), 'NAFTA at 20: Misleading Charges and Positive Achievements', Policy Brief, No. 14-13. Washington, DC: Peterson Institute for International Economics.

Kambourov, G. and I. Manovskii (2009a), 'Occupational Mobility and Wage Inequality', The Review of Economic Studies, 76(2), pp.731-759. 
Kambourov, G. and I. Manovskii (2009b), 'Occupational Specificity of Human Capital', International Economic Review, 50(1), pp.63-115.

Las Américas y el Mundo (n.d.), Poll. Mexico City: Centro de Investigación y Docencia Económicas (CIDE). Available at: https://www.lasamericasyelmundo. cide.edu/en/inicio (accessed 25February2019).

Pierce, J.R. and P.K. Schott (2014), 'The Surprisingly Swift Decline of U.S. Manufacturing Employment', CESifo Working Paper Series, No. 4563. Munich: Center for Economic Studies and Ifo Institute (CESifo).

Piketty, T. (2015), 'Capital in the Twenty-First Century', American Economic Review, 105(5), pp.48-53.

Rosen, S. (1981), 'The Economics of Superstars', American Economic Review, 71(5), pp.845-858.

Semega, J., M. Kollar, J. Creamer, and A. Mohanty (2019), Income and Poverty in the United States: 2018 - Current Population Reports. Washington, DC: United States Census Bureau.

Slaughter, M.J. (1998), 'International Trade and Labour-Market Outcomes: Results, Questions, and Policy Options', The Economic Journal, 108(450), pp.1452-1462.

US Census Bureau (2019), 'U.S. Trade in Goods and Services - Balance of Payments (BOP) Basis'. Available at: https://www.census.gov/foreign-trade/statistics/ historical/gands.pdf (accessed 25September2019).

US Customs and Border Protection Agency (n.d.), 'Fiscal Year Southwest Border Sector Apprehensions (FY 1960 - FY 2019)'. https://www.cbp.gov/sites/default/ files/assets/documents/2020-Jan/U.S.\%20Border\%20Patrol\%20Total\%20Apprehen sions $\% 20 \% 28 \mathrm{FY} \% 201925 \% 20-\% 20 \mathrm{FY} \% 202019 \% 29$.pdf

US International Trade Commission (2019), 'USITC DataWeb'. Available at: https://dataweb.usitc.gov/ (accessed 25October2019). 